\title{
Heat Treatment Eliminates 'Candidatus Liberibacter asiaticus' from Infected Citrus Trees Under Controlled Conditions
}

\author{
Michele T. Hoffman, Melissa S. Doud, Lisa Williams, Mu-Qing Zhang, Fang Ding, Ed Stover, David Hall, \\ Shouan Zhang, Lisa Jones, Mark Gooch, Laura Fleites, Wayne Dixon, Dean Gabriel, and Yong-Ping Duan
}

First, second, sixth, seventh, and fourteenth authors: United States Department of Agriculture-Agriculture Research Service, United States Horticultural Research Laboratory, Fort Pierce, FL 34945; third, ninth, tenth, and twelfth authors: Division of Plant Industry, Florida Department of Agriculture and Consumer Services, Gainesville, FL 32614; fourth author: Institute of Food and Agricultural Science, Indian River Research and Education Center, University of Florida, Fort Pierce, FL 34945; fifth and eighth authors, Institute of Food and Agricultural Science, Tropical Research and Education Center, University of Florida, Homestead, FL 33031; and eleventh and thirteenth authors: Plant Pathology Department, University of Florida, Gainesville, FL 32614.

Accepted for publication 23 September 2012.

\begin{abstract}
Hoffman, M. T., Doud, M. S., Williams, L., Zhang, M.-Q., Ding, F., Stover, E., Hall, D., Zhang, S., Jones, L., Gooch, M., Fleites, L., Dixon, W., Gabriel, D., and Duan, Y.-P. 2013. Heat treatment eliminates 'Candidatus Liberibacter asiaticus' from infected citrus trees under controlled conditions. Phytopathology 13:15-22.

Huanglongbing (HLB) is one of the most destructive diseases of citrus worldwide. The three known causal agents of HLB are species of $\alpha$ proteobacteria: 'Candidatus Liberibacter asiaticus', 'Ca. L. africanus', and ' $\mathrm{Ca}$. L. americanus'. Previous studies have found distinct variations in temperature sensitivity and tolerance among these species. Here, we describe the use of controlled heat treatments to cure HLB caused by ' $\mathrm{Ca}$. L. asiaticus', the most prevalent and heat-tolerant species. Using tempera-

ture-controlled growth chambers, we evaluated the time duration and temperature required to suppress or eliminate the ' $\mathrm{Ca}$. $\mathrm{L}$. asiaticus' bacterium in citrus, using various temperature treatments for time periods ranging from 2 days to 4 months. Results of quantitative polymerase chain reaction (qPCR) after treatment illustrate significant decreases in the ' $\mathrm{Ca}$. L. asiaticus' bacterial titer, combined with healthy vigorous growth by all surviving trees. Repeated qPCR testing confirmed that previously infected, heat-treated plants showed no detectable levels of ' $\mathrm{Ca}$. L. asiaticus', while untreated control plants remained highly infected. Continuous thermal exposure to 40 to $42^{\circ} \mathrm{C}$ for a minimum of $48 \mathrm{~h}$ was sufficient to significantly reduce titer or eliminate ' $\mathrm{Ca}$. L. asiaticus' bacteria entirely in HLB-affected citrus seedlings. This method may be useful for the control of ' $\mathrm{Ca}$. Liberibacter'-infected plants in nursery and greenhouse settings.
\end{abstract}

Citrus huanglongbing (HLB) is caused by three species of fastidious, phloem-restricted $\alpha$-proteobacteria: 'Candidatus Liberibacter asiaticus', ' $\mathrm{Ca}$. L. africanus', and ' $\mathrm{Ca}$. Liberibacter americanus' (9). All three are vectored by two phloem-feeding psyllid species, the Asian citrus psyllid Diaphorina citri Kuwayama and African citrus psyllid Trioza erytreae (Del Guercio) (9). Current HLB control strategies focus on the prevention of psyllid infestation and transmission of HLB within citrus groves (9). Unfortunately, once ' $\mathrm{Ca}$. L. asiaticus', ' $\mathrm{Ca}$. L. americanus', or ' $\mathrm{Ca}$. L. africanus' has been transmitted, there are no options available to growers to prevent the increased growth of the pathogen in the tree, followed by the decline or destruction of the infected trees. Often these trees are at the beginning years of fruit production, adding to the economic impact of HLB. In Florida alone, HLB has caused an estimated $\$ 3.63$ billion in lost revenue since 2006 (12).

Distinctions in temperature sensitivity between these Liberibacter spp. have been found within specific citrus production regions (e.g., Brazil, China, and South Africa). Whereas ' $C a$. L. asiaticus' tolerates temperatures $>30^{\circ} \mathrm{C}$, ' $\mathrm{Ca}$. L. africanus' thrives only in the narrow range of 22 to $25^{\circ} \mathrm{C}(2,14)$. Researchers found that ' $C a$. L. africanus'-infected seedlings remained asymptomatic when maintained in growth chambers at $32^{\circ} \mathrm{C}(16 \mathrm{~h} /$ day $)$ for 30 weeks (2). Similarly, Aubert et al. (1) documented the absence of HLB symptoms on citrus and other indigenous plants belong-

Corresponding author: Y.-P. Duan; E-mail address: yongping.duan@ars.usda.gov

http://dx.doi.org/10.1094/PHYTO-06-12-0138-R

(C) 2013 The American Phytopathological Society ing to the Rutaceae family in five sub-Saharan regions of Africa where the daily maximum temperature was never $<25^{\circ} \mathrm{C}$ and mean annual maximum temperatures were $>30^{\circ} \mathrm{C}$ (1). Additional studies conducted in Brazil using growth chambers found that the heat-tolerant ' $\mathrm{Ca}$. L. asiaticus' thrived at temperatures as high as $35^{\circ} \mathrm{C}$ whereas ' $\mathrm{Ca}$. L. americanus' could no longer be detected at $>32^{\circ} \mathrm{C}$ (21). A similar negative influence of elevated temperature on Liberibacter titer was also found in similar studies of ' $\mathrm{Ca}$. L. africanus' and ' $\mathrm{Ca}$. L. asiaticus' infections of periwinkle (Catharanthus roseus; Apocynaceae) (7). In this study, disease symptoms similar to those found in citrus occurred in periwinkle at both temperatures for ' $\mathrm{Ca}$. L. asiaticus', whereas symptoms from ' $C a$. L. africanus' infection were never present at the higher temperature (7).

Recent studies have concluded that ' $\mathrm{Ca}$. L. asiaticus' is capable of growing at ambient temperatures as high as $35^{\circ} \mathrm{C}$; however, the upper threshold of its temperature tolerance has not been explored (8). In addition, analyses of the ' $\mathrm{Ca}$. L. asiaticus' genome revealed two prophages, both of which can enter a lytic cycle (31). The lytic cycles of many prophages, including Escherichia coli and Xylella fastidiosa prophages, can be induced by heat stress, resulting in cell lysis $(5,25,27)$. Therefore, it may be possible to use temperature treatments $>35^{\circ} \mathrm{C}$ to either kill ' $\mathrm{Ca}$. L. asiaticus' cells directly or induce the phage to lyse the bacterium.

Thermal therapy ("thermotherapy") treatments have been used for decades to prevent or eliminate diseases in plants. There are reports as early as 1936 in which dry heat and hot-water treatments were utilized to cure peach yellows and other chlorotic diseases caused by viral infections (16). Heat treatment of sugarcane still remains an effective component of routine propagation and is 
used to prevent numerous diseases, including ratoon stunting disease (Leifsonia xyli subsp. xyli formally Clavibacter xyli subsp. $x y l i)(4,13)$ and grassy shoot disease ('Candidatus Phytoplasma') (28). Thermotherapy was also found to be highly effective for the inactivation of Citrus tristeza virus in budwood, preventing citrus quick decline disease $(10,11,23)$. Evidence that thermotherapy can control HLB was first documented in China, where phenotypic symptoms of HLB were eliminated in budwood and seedlings after the material was exposed to moist, hot air of 49 to $50^{\circ} \mathrm{C}$ for 50 to $60 \mathrm{~min}$ (20). Another study demonstrated that treating infected citrus seedlings three times with hot water (47 to $50^{\circ} \mathrm{C}$ for 6 to $12 \mathrm{~min}$ ) every $24 \mathrm{~h}$ for a total of three treatments produced asymptomatic leaves for a minimum of 29 months after treatment (19). The purpose of this study was to evaluate various temperature treatment regimes and methods using ' $\mathrm{Ca}$. L. asiaticus'-infected citrus buds, potted citrus, and periwinkle in order to determine the feasibility of thermotherapy as a remedy for ' $C a$. L. asiaticus'-infected citrus nursery plants.

\section{MATERIALS AND METHODS}

Prior to all citrus experiments, different varieties of citrus scion were grafted with buds or budwood removed from mature, ' $\mathrm{Ca}$. L. asiaticus'-positive citrus trees, symptomatic for HLB. Budwood experiments were conducted at the University of Florida (UF) facility in Gainesville, FL. All other experiments were completed at the United States Horticultural Laboratory (USHRL) in Ft. Pierce, FL. For the budwood experiments, thermotherapy was immediately applied to the freshly budded nursery trees prior to potential systemic infection from the dormant buds while, in the remaining experiments, thermotherapy was applied to the similarly sized nursery trees after systemic infection was established by grafting HLB-affected scions onto healthy seedlings. Periwinkle plants were grafted with ' $C a$. L. asiaticus'-infected periwinkle stems and monitored for disease symptoms. Control plants were maintained continuously in HLB-restricted, psyllid-proof greenhouses. Before and after designated treatments, each plant was returned to the same HLB isolation greenhouse, where they received weekly fertilizer management (Peters 20-10-20 Special). Temperatures in the greenhouse fluctuated from 20 to $36^{\circ} \mathrm{C}$.

Heat-treatment assay using dormant budwood. Four types of citrus (Citrus paradisi 'Ruby Red', $C$. sinensis 'Hamlin', $C$. volkameriana, and C. maxima 'Pummelo') were used as sources of infected budwood. All budwood source trees were symptomatic for HLB and tested ' $\mathrm{Ca}$. L. asiaticus' positive by conventional polymerase chain reaction (PCR) (15). Three dormant buds from each infected citrus type were grafted onto each of 12 uninfected Poncirus trifoliata $\times C$. sinensis ('Troyer') rootstocks (6- to 12-month-old, greenhouse-grown potted seedlings), resulting in 36 grafted buds of each citrus type on Troyer rootstock. Buds were wrapped with budding tape to maintain dormancy and placed in the UF greenhouse for 4 weeks. Eighteen grafted buds of each type were then heat treated in an EGC M48 (Environmental Growth Chambers, Chagrin Falls, $\mathrm{OH}$ ) growth chamber maintained at $40^{\circ} \mathrm{C}$ for a $16-\mathrm{h}$ photoperiod and $30^{\circ} \mathrm{C}$ for an 8 -h dark period. This $40 / 30^{\circ} \mathrm{C}$ heat treatment continued for 4 months. The remaining 18 grafted buds of each type were left in the greenhouse for the 4-month duration. After 4 months, both the heat-treated and untreated buds were unwrapped, and bud viability was determined after another 3 months. PCR detection was performed only on tender leaves removed from fresh shoots emerging from the viable buds on up to six different citrus plants of each variety. Testing was by both conventional PCR (15) and quantitative (q)PCR as described below.

Preliminary screening of heat-treatment effects on ' $\mathrm{Ca}$. $\mathrm{L}$. asiaticus'-infected citrus. Three-year-old potted citrus trees, $\approx 0.5$ to $0.8 \mathrm{~m}$ tall and confirmed to be systemically ' $C a$. L. asiaticus' infected by qPCR (as described below), were exposed to various thermotherapy regimes in a Conviron CMP5000 growth chamber (Winnipeg, Canada), with fluorescent lamps at $40 \%$ intensity, a $12-\mathrm{h}$ photoperiod, and $50 \%$ relative humidity $(\mathrm{RH})$. Two $C$. reticulata (samples HT 1 to 2), five $C$. paradisi (samples HT 3 to 7), and three $C$. limon trees (samples HT 8 to 10) were exposed to a constant temperature of $40^{\circ} \mathrm{C}$ for 10 days. In addition, three ' $\mathrm{Ca}$. L. asiaticus'-negative potted citrus trees (samples HT $13 \mathrm{C}, 14 \mathrm{C}$, and $15 \mathrm{C}$ ) underwent thermotherapy of $40^{\circ} \mathrm{C}$ for 10 days. Two additional $C$. limon trees (samples HT 11 and 12) were exposed to $42^{\circ} \mathrm{C}$ for 10 days while an additional $C$. limon and $C$. paradisi underwent treatment at a constant $45^{\circ} \mathrm{C}$ for 3 days. Three ' $\mathrm{Ca}$. L. asiaticus' infected citrus (samples HT 16C, 17C, and $18 \mathrm{C}$ ) received no treatment and remained in the same USHRLrestricted, psyllid-proof greenhouse. Following treatments, all trees were tested for ' $\mathrm{Ca}$. L. asiaticus' using qPCR.

Optimization of thermal treatments to eradicate ' $C a$. $\mathbf{L}$. asiaticus' in citrus. Thirty ' $\mathrm{C} a$. L. asiaticus'-positive 2.5-year-old potted $C$. paradisi Macfadyen trees, $\approx 0.45 \mathrm{~m}$ tall in 1 -gallon containers, were randomly assigned to one of three treatment groups. All trees were tested $\approx 1$ week before treatment and 30,60 , and 270 days after treatment (DAT) for ' $\mathrm{Ca}$. L. asiaticus' using qPCR, as described below. The treatments were (i) constant exposure at $40^{\circ} \mathrm{C}$ (samples TOA 1 to 9), (ii) daily cycle of $42^{\circ} \mathrm{C}$ for $19 \mathrm{~h}$ followed by $30^{\circ} \mathrm{C}$ for $5 \mathrm{~h}$ (samples TOA 11 to 18), and (iii) daily cycle of $45^{\circ} \mathrm{C}$ for $16 \mathrm{~h}$ followed by $30^{\circ} \mathrm{C}$ for $8 \mathrm{~h}$ (samples TOA 19 to 27). All three treatments were performed at $50 \% \mathrm{RH}$ and 12-h photoperiods for time periods of 2, 4, or 6 days, respectively. For each treatment regime, three trees were incubated in the growth chamber for 2, 4, or 6 days before placement in the USHRL HLB isolation greenhouse for observations. One infected tree from each treatment regime (sample numbers TOA 1C, TOA 2C, and TOA $3 \mathrm{C}$ ) was held in the isolation greenhouse to serve as an untreated control.

' $C a$. L. asiaticus'-infected periwinkle thermal treatments. To determine whether heat-treatment responses would be comparable in a non-citrus host, similar experiments were completed using periwinkle (Catharanthus roseus). Periwinkle plants, graft inoculated 3 months earlier from one ' $\mathrm{Ca}$. L. asiaticus'-infected periwinkle plant, were selected based on pronounced symptoms of ' $C a$. L. asiaticus' infection. Three ' $C a$. L. asiaticus'-infected periwinkle and three uninfected healthy controls were maintained for 7 days in the growth chamber with conditions set to $40^{\circ} \mathrm{C}$ at $50 \% \mathrm{RH}$. A second periwinkle experiment used three infected and three uninfected plants treated with conditions set to $40^{\circ} \mathrm{C}$ at $50 \%$ $\mathrm{RH}$ for 7 days, followed by an increase in temperature to $42^{\circ} \mathrm{C}$ for an additional 7 days. ' $\mathrm{Ca}$. L. asiaticus' was detected by qPCR before treatment and at 30 and 90 DAT, as described below.

Sample preparation and DNA extraction. For each plant, symptomatic leaf samples of diseased tissue were collected before treatment to determine initial threshold cycle $(\mathrm{Ct})$ values of ' $\mathrm{Ca}$. L. asiaticus'. Plants were sampled at 30 DAT if tissue was available for testing. Recently, hardened flush continued to be sampled after heat treatment at various time points (e.g., 60, 90, and 180 DAT). Leaf tissue was either immediately processed or stored at $4^{\circ} \mathrm{C}$ until processed. Total genomic DNA was extracted using a modified Qiagen DNeasy Plant mini kit protocol (Qiagen, Germantown, MD). Briefly, $200 \mathrm{mg}$ of leaf midribs were finely cut and placed in sterile 2-ml tubes with silicone-carbide shards, 2.3-mm chrome-steel beads, and $800 \mu \mathrm{l}$ of AP1 extraction buffer. Tissue was macerated using a Fast Prep-24 homogenizer (MP Biomedical, Solon, $\mathrm{OH}$ ) at speed 6.5 for $120 \mathrm{~s}$. After adding $8 \mu \mathrm{l}$ of RNase A, samples were incubated for $30 \mathrm{~min}$ in a $65^{\circ} \mathrm{C}$ water bath. After $200 \mu \mathrm{l}$ of AP2 buffer was added, samples were incubated on ice for $5 \mathrm{~min}$ and further processed with the standard published protocol for the extraction. Final DNA samples were eluted in $100 \mu \mathrm{l}$ of sterile water and stored at $-30^{\circ} \mathrm{C}$.

PCR methods. All real-time PCR amplifications were performed in either a Cepheid Smart Cycler 900 or an Eppendorf 
Mastercycler realplex thermal cycler (Eppendorf, Hauppauge, $\mathrm{NY}$ ) using ' $\mathrm{Ca}$. L. asiaticus'-specific primers HLBasf, HLBr, and TaqMan probe HLBp $(100 \mu \mathrm{M})$ that target the $16 \mathrm{~S}$ rDNA region of 'Ca. L. asiaticus' (17). Amplification settings for the 'Ca. L. asiaticus' primers with the TaqMan probe used $15 \mu \mathrm{l}$ of reaction mixture, started with a $95^{\circ} \mathrm{C}$ initial denaturation step for $5 \mathrm{~min}$, and was followed by 40 cycles at $95^{\circ} \mathrm{C}$ for $3 \mathrm{~s}$ and then $60^{\circ} \mathrm{C}$ for $30 \mathrm{~s}$. All reactions were performed in duplicate using the "fast" temperature mode. The mean $\mathrm{Ct}$ was used to estimate ' $\mathrm{Ca}$. L. asiaticus' titer (cells per gram of fresh weight of citrus tissue) based on the formula $Y=13.82-0.2866 X$, where $Y$ is defined as the log of the target copy number and $X$ is the $\mathrm{Ct}$ result of the qPCR assay for the sample (18). Conventional PCR was performed as described by Jagoueix et al. (15) using the primer pair OI1/OI2c.

Statistical analysis. To evaluate the changes in $\mathrm{Ct}$ values for treatments, statistical analyses using analysis of variance (ANOVA), Student's $t$ test, and Tukey's honestly significant difference (HSD) were completed with JMP 8.0 (SAS Institute Inc., Cary, NC). All qPCR Ct results displaying no detected level of ' $\mathrm{Ca}$. L. asiaticus' 16S rDNA were arbitrarily assigned the value of 40 , indicating zero detection after 40 cycles. ' $C a$. L. asiaticus' levels at $\mathrm{Ct}$ value $>36.9$ using TaqMan probe were considered ' $\mathrm{Ca}$. L. asiaticus' negative (18).

\section{RESULTS}

Dormant budwood response to heat treatment. In total, 144 grafted buds of grapefruit, sweet orange, lemon, and pummelo were obtained on a total of 48 Troyer rootstocks. Half of these were heat treated for 4 months on a $40^{\circ} \mathrm{C}, 16$-h light cycle, with a $30^{\circ} \mathrm{C}, 8$-h dark period each day. The other half were untreated controls maintained in a greenhouse. Of the potentially ' $\mathrm{Ca}$. L. asiaticus'-infected buds, 33 to $100 \%$ sprouted to produce viable shoots, regardless of whether thermotherapy was used or not (Table 1). There was no evident deleterious effect of the 4-month $40 / 30^{\circ} \mathrm{C}$ heat treatment on bud sprouting after treatment compared with controls. In these experiments, a single bud sprouted on 33 trees $(70.2 \%)$, two buds on 10 trees $(21.3 \%)$, three buds on two trees $(4.2 \%)$, and no buds on two 2 trees $(4.2 \%)$ regardless of treatment applied; the low number of bud sprouts limited the number of trees that could be sampled for ' $\mathrm{Ca}$. L. asiaticus' to a range of four to six trees. The $40 / 30^{\circ} \mathrm{C}$ heat treatment appeared to provide some benefit in terms of reducing the number of buds with ' $\mathrm{Ca}$. L. asiaticus'; only 3 of $24(12.5 \%)$ thermotherapytreated buds were ' $C a$. L. asiaticus' positive after 12 months, whereas 11 of $21(52 \%)$ untreated buds were ' $\mathrm{Ca}$. L. asiaticus' positive after 12 months (Table 1).

Heat-treatment preliminary screening effects on ' $\mathrm{Ca}$. $\mathrm{L}$. asiaticus'-infected citrus. Ten HLB-affected trees (two $C$. reticulata, five $C$. paradisi, and three $C$. limon) were exposed to continuous heat treatment of $40^{\circ} \mathrm{C}$ for 10 days. For each infected citrus plant, symptomatic leaf samples were collected before thermotherapy treatment to determine the initial $\mathrm{Ct}$ values of ' $\mathrm{Ca}$. L. asiaticus'. The average TaqMan qPCR Ct value for the 12 infected trees (excluding controls) was 26.09, representing an average ' $C a$. L. asiaticus' titer of $6.59 \times 10^{8}$ cells/g of tissue (Table 2) (18). After 10 days of heat treatment at $40^{\circ} \mathrm{C}$, all disease symptoms on new growth were eliminated. By 90 DAT at $40^{\circ} \mathrm{C}$, a 989-fold decline in estimated bacterial titer was observed (mean $\mathrm{Ct}$ value $=36.04,95 \%$ confidence interval $[\mathrm{CI}]=32.53$ to 39.55 , $t_{9}=5.08$, two-sided $\left.P>0.0007\right)$. No differences due to citrus species were observed based on ANOVA. By 180 DAT, all 12 treated trees sampled were negative for ' $\mathrm{Ca}$. L. asiaticus', whereas the infected control trees without thermotherapy continued to decline and remained ' $\mathrm{Ca}$. L. asiaticus' positive. The three healthy trees exposed to $40^{\circ} \mathrm{C}$ for 10 days did not display any adverse response to the thermal treatment. The trees continued to flush, producing asymptomatic leaves that remained ' $\mathrm{Ca}$. L. asiaticus' negative throughout the study (i.e., having a $\mathrm{Ct}$ value $>36.9$ ) (Table 2).

Two C. limon trees (HT 11 and 12) were exposed to continuous $42^{\circ} \mathrm{C}$ for 10 days (Table 2). At 30 DAT, no characteristic symptoms of HLB were observed in any of the new growth on HT 11 and HT 12, although there was serious leaf scorch and stem damage to the distal regions of the plants. ' $\mathrm{Ca}$. L. asiaticus' was not detected by 30 DAT, and ' $C a$. L. asiaticus' remained undetected at the last sampling at 270 DAT (Table 2). Two infected citrus plants were placed in the growth chamber for 3 days at constant $45^{\circ} \mathrm{C}$. The trees had severe tissue damage and were dead within a month after treatment.

Citrus trees treated at either 42 or $40^{\circ} \mathrm{C}$ for 10 days displayed a pronounced vigorous growth response within 30 to 60 DAT, as evidenced by healthy new flush on rootstock and scion as well as vigorously new root growth (Fig. 1). These phenotypic results, combined with repeated real-time PCR results, suggested that the pathogen had been significantly reduced or eliminated by these heat treatments. Additional screenings of infection status for

TABLE 1. Effects of heat treatment on the bud viability and survival of the huanglongbing bacterium in grafted trees

\begin{tabular}{|c|c|c|c|c|}
\hline \multirow[b]{2}{*}{ Trees } & \multicolumn{2}{|c|}{ Buds } & \multicolumn{2}{|c|}{ Positive/total plants ${ }^{\mathrm{a}}$} \\
\hline & $N^{\mathrm{b}}$ & Total (\%) & 6 months & 12 months \\
\hline \multicolumn{5}{|l|}{ Ruby Red Grapefruit } \\
\hline Thermotherapy & 18 & & & \\
\hline Living & 14 & 77.8 & $0 / 6$ & $1 / 6$ \\
\hline Sprouted & 6 & 33.3 & $\ldots$ & $\ldots$ \\
\hline Unsprouted & 8 & 44.4 & $\ldots$ & $\ldots$ \\
\hline Dead & 4 & 22.2 & $\ldots$ & $\ldots$ \\
\hline Greenhouse controls & 18 & & & \\
\hline Living & 17 & 94.4 & $1 / 5$ & $2 / 5$ \\
\hline Sprouted & 7 & 38.9 & $\ldots$ & $\ldots$ \\
\hline Unsprouted & 10 & 55.6 & $\ldots$ & $\ldots$ \\
\hline Dead & 1 & 5.6 & $\ldots$ & $\ldots$ \\
\hline \multicolumn{5}{|l|}{ Hamlin Sweet Orange } \\
\hline Thermotherapy & 18 & & & \\
\hline Living & 18 & 100.0 & $2 / 6$ & $2 / 6$ \\
\hline Sprouted & 12 & 66.7 & $\ldots$ & $\ldots$ \\
\hline Unsprouted & 6 & 33.3 & $\ldots$ & $\ldots$ \\
\hline Dead & 0 & 0.0 & $\ldots$ & $\ldots$ \\
\hline Greenhouse controls & 18 & & & \\
\hline Living & 18 & 100.0 & $6 / 6$ & $6 / 6$ \\
\hline Sprouted & 7 & 38.9 & $\ldots$ & $\ldots$ \\
\hline Unsprouted & 11 & 61.6 & $\ldots$ & $\ldots$ \\
\hline Dead & 0 & 0.0 & $\ldots$ & $\ldots$ \\
\hline \multicolumn{5}{|l|}{ Volkamer Lemon } \\
\hline Thermotherapy & 18 & & & \\
\hline Living & 12 & 66.7 & $0 / 6$ & $0 / 6$ \\
\hline Sprouted & 9 & 50.0 & $\ldots$ & $\ldots$ \\
\hline Unsprouted & 3 & 16.7 & $\ldots$ & $\ldots$ \\
\hline Dead & 6 & 33.3 & $\ldots$ & $\ldots$ \\
\hline Greenhouse controls & 18 & & & \\
\hline Living & 18 & 100.0 & $3 / 6$ & $3 / 6$ \\
\hline Sprouted & 8 & 44.4 & $\ldots$ & $\ldots$ \\
\hline Unsprouted & 10 & 55.6 & $\ldots$ & $\ldots$ \\
\hline Dead & 0 & 0.0 & $\ldots$ & $\ldots$ \\
\hline \multicolumn{5}{|l|}{ Pummelo } \\
\hline Thermotherapy & 18 & & & \\
\hline Living & 10 & 55.6 & $0 / 6$ & $0 / 6$ \\
\hline Sprouted & 7 & 38.9 & $\ldots$ & $\ldots$ \\
\hline Unsprouted & 3 & 16.7 & $\ldots$ & $\ldots$ \\
\hline Dead & 8 & 44.4 & $\ldots$ & $\ldots$ \\
\hline Greenhouse controls & 15 & & & \\
\hline Living & 8 & 53.3 & $0 / 4$ & $0 / 4$ \\
\hline Sprouted & 5 & 33.3 & $\ldots$ & $\ldots$ \\
\hline Unsprouted & 3 & 20.0 & $\ldots$ & $\ldots$ \\
\hline Dead & 7 & 46.7 & $\ldots$ & $\ldots$ \\
\hline
\end{tabular}

a 'Candidatus Liberibacter asiaticus' positive/total plants. Polymerase chain reaction testing was performed on up to six different trees; samples from each tree were taken from a sprouted bud.

b Number of total buds. 
surviving trees exposed to temperatures $>40^{\circ} \mathrm{C}$ have remained 'Ca. L. asiaticus' free (Table 2).

Eradication of ' $\mathrm{Ca}$. L. asiaticus' in citrus using optimized thermal treatments. Thirty $C$. paradisi were used to examine whether ' $C a$. L. asiaticus' could be eliminated with a shorter period of thermotherapy (2, 4, or 6 days) interrupted by relatively cool periods. Because citrus exposed to a constant temperature of 42 and $45^{\circ} \mathrm{C}$ displayed serious tissue damage, the temperature regime was modified to $42^{\circ} \mathrm{C}$ for $19 \mathrm{~h}$ followed by $30^{\circ} \mathrm{C}$ for $5 \mathrm{~h}$, $45^{\circ} \mathrm{C}$ for $16 \mathrm{~h}$, and $30^{\circ} \mathrm{C}$ for $8 \mathrm{~h}$ to minimize damage to plant tissue while still exposing the bacteria to high temperatures. At 30 DAT, citrus trees exposed for at 45 and $30^{\circ} \mathrm{C}$ were almost completely defoliated and could not be sampled (Table 3). By 60 DAT, these seedlings had recovered, displaying vigorous healthy new growth, predominately from the basal portions of the trunks. As expected, foliar damage was generally greater on trees with longer exposure to $45^{\circ} \mathrm{C}$. Trees exposed to $42^{\circ} \mathrm{C}$ displayed initial defoliation similar to that of the $45^{\circ} \mathrm{C}$ group, although the overall recovery by 30 DAT was more rapid. The groups receiving the $40^{\circ} \mathrm{C}$ treatment displayed minimal leaf damage, with healthy new growth prominent by 30 DAT.

The mean $\mathrm{Ct}$ value measured before treatment for all 30 plants was 21.3 (95\% CI $=20.58$ to $22.18 \mathrm{Ct}$ values). Regardless of the treatment conditions, all 27 trees had undetected levels of ' $\mathrm{Ca}$. L. asiaticus' (Ct value > 36.9) at 60 DAT while two controls had Ct values of $\approx 21$ and the third (sample number TOA 3C) was nearly defoliated due to continued ' $\mathrm{Ca}$. L. asiaticus' infection (data not shown). When compared with controls, the average change in $\mathrm{Ct}$ value for treated plants 60 DAT was an increase of 18.9 while the controls remained the same (ANOVA $F_{3,29}=60.06 ; P<0.0001$ ). Comparisons between treatments suggested that all thermotherapy regimes were equally effective, regardless of temperature or exposure time (Tukey's HSD; $q=2.504 ; \alpha=0.050$ ).

' $\boldsymbol{C a}$. L. asiaticus'-infected periwinkle response to thermal treatments. To determine whether thermal therapy could suppress ' $\mathrm{Ca}$. L. asiaticus' in another host, heat treatments of $40^{\circ} \mathrm{C}$ for 10 days and an extended treatment of 1 week at $40^{\circ} \mathrm{C}$ and a second week at $42^{\circ} \mathrm{C}$ were applied to 12 periwinkle plants (six infected and six uninfected) (Table 4). The mean $\mathrm{Ct}$ value for the infected plants before treatment was 24.7 (95\% CI $=21.2$ to 28.2 $\mathrm{Ct}$ values). Thermal therapy treatment was completed on three ' $C a$. L. asiaticus'-infected periwinkle plants and three ' $C a$. L. asiaticus'-free periwinkle plants in the growth chamber using $40^{\circ} \mathrm{C}$ for 10 days, and the same temperature regime was used to treat six varieties of HLB-affected citrus. Real-time PCR results showed a change in $\mathrm{Ct}$ values for two of the three infected plants for the first replicate while no differences were seen in the uninfected plants (Table 4). Closer examination of the remaining plant (PW 502) showed a symptomatic branch that was positive for ' $\mathrm{Ca}$. L. asiaticus'. With the more aggressive $40 / 42^{\circ} \mathrm{C}$ regime, decreases of ' $C a$. L. asiaticus' titer levels were observed in all three infected plants, and ' $C a$. L. asiaticus' was not detected 90 DAT. Although plants displayed wilting and heat stress during thermal treatment, all but one regained healthy growth after returning to the greenhouse (Table 4).

\section{DISCUSSION}

' $C a$. L. asiaticus' is tolerant of temperatures as high as $35^{\circ} \mathrm{C}$, both distinguishing this species from the other two HLB infective agents and suggesting thermotherapy as one potential control method (9). Although earlier studies indicated that HLB-associated symptoms could be suppressed when infected budwood and seedlings were exposed to temperatures $>47^{\circ} \mathrm{C}$, no research has addressed the upper threshold of ' $\mathrm{Ca}$. L. asiaticus' viability in planta using quantifiable molecular approaches $(19,20)$.

Thermotherapy experiments reported here first focused on evaluating the potential use of thermotherapy to ensure that buds removed from ' $C a$. L. asiaticus'-infected trees would be ' $C a$. L. asiaticus' free following treatment of the infected, dormant buds. However, exposure of dormant buds to temperature cycles of $40 / 30^{\circ} \mathrm{C}$, even for a relatively long duration of 4 months, provided no assurance of curing ' $\mathrm{Ca}$. L. asiaticus'.

Exposure of potted citrus trees to temperatures of 40 to $42^{\circ} \mathrm{C}$ were highly successful in reducing the ' $\mathrm{Ca}$. L. asiaticus' pathogen from what were extremely unhealthy trees. Interestingly, residual ' $C a$. L. asiaticus' bacteria, possibly representative of dead bacteria, remained detectable in the older, hardened leaves of test

TABLE 2. Threshold cycle $(\mathrm{Ct})$ values for individual citrus trees before and after constant high-temperature $\left(40^{\circ} \mathrm{C}\right)$ treatment in a growth chamber as determined by quantitative polymerase chain reaction $(\mathrm{qPCR})^{\mathrm{a}}$

\begin{tabular}{|c|c|c|c|c|c|c|c|c|c|c|}
\hline \multirow[b]{2}{*}{ Sample ${ }^{b}$} & \multirow[b]{2}{*}{ Cultivar ${ }^{\mathrm{c}}$} & \multirow[b]{2}{*}{$\operatorname{Temp}\left({ }^{\circ} \mathrm{C}\right)^{\mathrm{d}}$} & \multirow[b]{2}{*}{ Time (days) } & \multicolumn{5}{|c|}{$\mathrm{Ct}$ value } & \multicolumn{2}{|c|}{ 'Ca. L. asiaticus' titer } \\
\hline & & & & Initial & $30 \mathrm{DAT}$ & 90 DAT & 180 DAT & Most recent/DAT & Initial & $30 \mathrm{DAT}$ \\
\hline HT 1 & Citrus reticulata & 40 & 10 & 36.88 & ND & 35.15 & ND & $\mathrm{ND} / 420$ & $1.48 \mathrm{E}+05$ & ND \\
\hline HT 2 & C. reticulata & 40 & 10 & 22.92 & 30.85 & 27.88 & N/A & $\mathrm{ND} / 270$ & $1.49 \mathrm{E}+09$ & $7.93 \mathrm{E}+06$ \\
\hline HT 4 & C. paradisi & 40 & 10 & 23.29 & ND & ND & N/A & $\mathrm{ND} / 270$ & $1.16 \mathrm{E}+09$ & ND \\
\hline HT 5 & C. paradisi & 40 & 10 & 26.72 & ND & 31.21 & N/A & $\mathrm{ND} / 270$ & $1.21 \mathrm{E}+08$ & ND \\
\hline HT 6 & C. paradisi & 40 & 10 & 27.82 & ND & ND & N/A & $\mathrm{ND} / 270$ & $5.86 \mathrm{E}+07$ & ND \\
\hline HT 10 & C. limon & 40 & 10 & 23.75 & 30.17 & 29.18 & N/A & $\mathrm{ND} / 270$ & $8.59 \mathrm{E}+08$ & $1.24 \mathrm{E}+07$ \\
\hline HT 11 & C. limon & 42 & 10 & 29.45 & ND & ND & ND & $\mathrm{ND} / 270$ & $2.00 \mathrm{E}+07$ & ND \\
\hline HT 12 & C. limon & 42 & 10 & 22.74 & ND & ND & ND & $\mathrm{ND} / 270$ & $1.67 \mathrm{E}+09$ & ND \\
\hline HT $13 \mathrm{C}$ & Healthy & 40 & 10 & ND & ND & ND & ND & $\mathrm{ND} / 390$ & ND & ND \\
\hline HT 14C & Healthy & 40 & 10 & ND & ND & ND & ND & $\mathrm{ND} / 390$ & ND & ND \\
\hline HT $15 \mathrm{C}$ & Healthy & 40 & 10 & ND & ND & ND & N/A & N/A & ND & ND \\
\hline
\end{tabular}

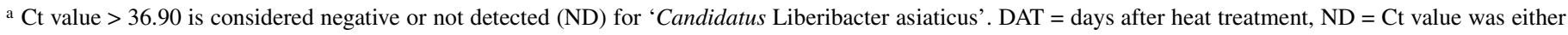
$>36.9$ or ND within 40 cycles of qPCR and sample was considered negative for ' $\mathrm{Ca}$. L. asiaticus', and N/A indicates that tree was not sampled.

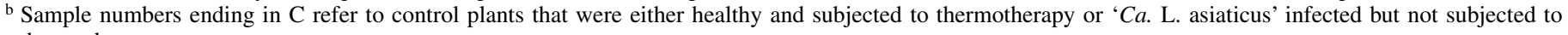
thermotherapy.

c Infected = infected with ' $\mathrm{Ca}$. L. asiaticus'.

d Temperature; NT = no treatment.

e Titer is per gram of tissue. 

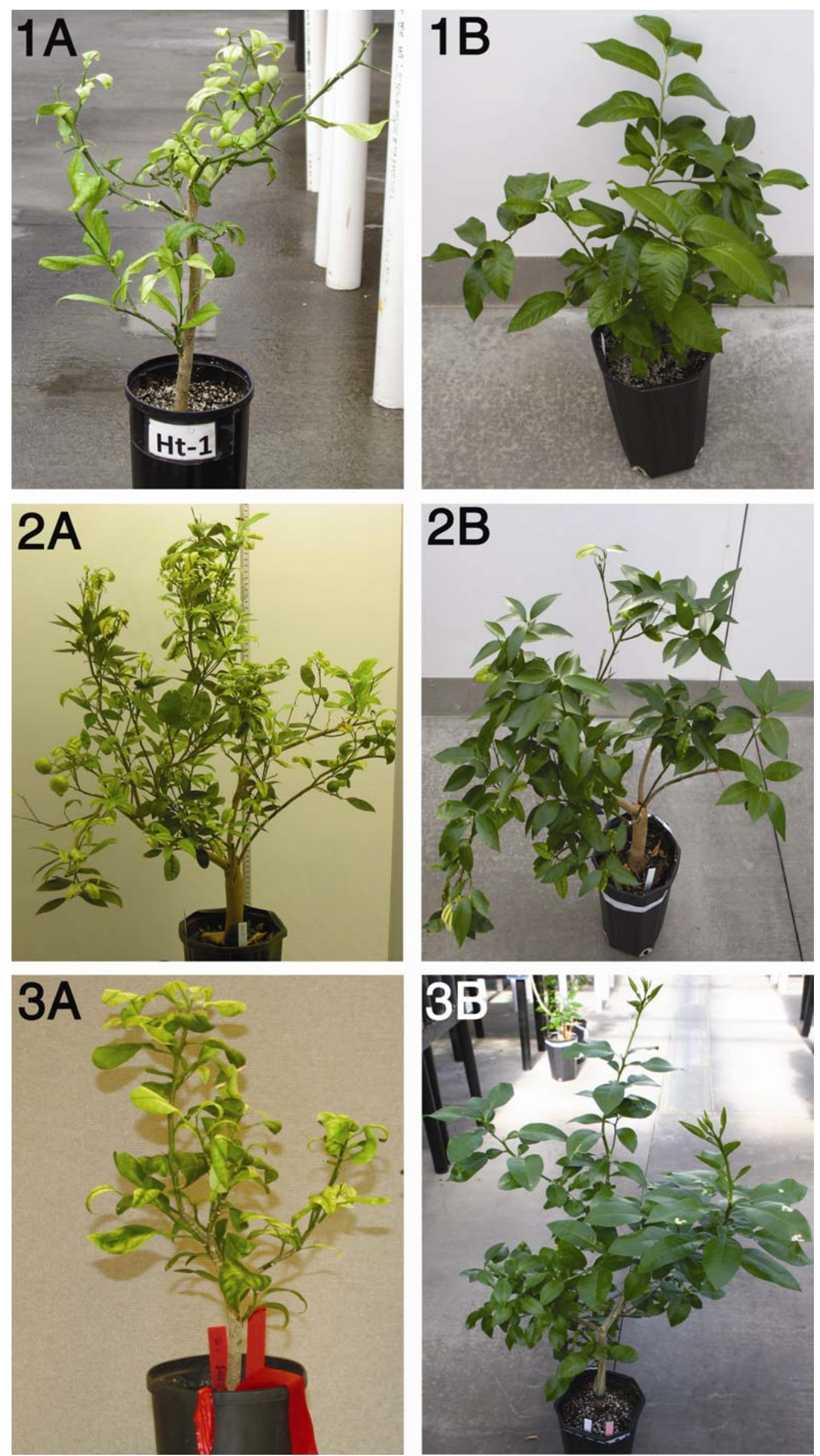

Fig. 1. Phenotypes of three citrus varieties before and after exposure to $40^{\circ} \mathrm{C}$ for 10 days. 1A, Citrus limon before and 1B, 270 days after treatment (DAT); $\mathbf{2 A}, C$. reticulata before and $\mathbf{2 B}, 150$ DAT; and $\mathbf{3 A}, C$. paradisi before and 3B, 150 DAT. 
samples, regardless of the treatment regimen, although with diminished titer levels compared with treatment titers observed prior to treatment (data not shown). Trees growing in a psyllidproof greenhouse after such treatments have remained ' $\mathrm{Ca}$. L. asiaticus' free for over 2 years, indicating the complete absence of viable ' $\mathrm{Ca}$. L. asiaticus' in these trees.

Thermotherapy was also found to be an effective means of suppressing or eradicating ' $\mathrm{Ca}$. L. asiaticus' in periwinkle, a model system for studying HLB. Preliminary results indicate that a longer duration of heat treatment is needed to reduce ' $\mathrm{Ca}$. $\mathrm{L}$. asiaticus' infection in periwinkle. Although 2 days of $40^{\circ} \mathrm{C}$ was sufficient to control HLB infection in citrus seedlings, ' $\mathrm{Ca}$. L. asiaticus' was still detectable in two of three periwinkle plants after 10 days of heat treatment. The increase in both temperature and duration improved suppression of ' $\mathrm{Ca}$. L. asiaticus' in periwinkle. Optimization of thermotherapy treatment for ' $\mathrm{Ca}$. L. asiaticus'-infected periwinkle is continuing.

The reduction of ' $\mathrm{Ca}$. L. asiaticus' titer in both citrus and periwinkle after exposure to elevated temperatures suggests that ' $\mathrm{Ca}$. L. asiaticus' bacteria are adversely affected and can even be eliminated by exposure to high temperature. It is possible that heat stress may have induced plant defense responses that help combat the infection. Heat stress in plants is defined as the arrested development, after a rise in temperature above a predetermined

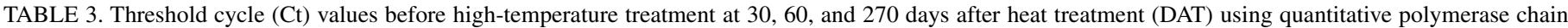
reaction (qPCR) with HLBaspr primers (17) for citrus time optimization assay ${ }^{a}$

\begin{tabular}{|c|c|c|c|c|c|c|c|c|c|}
\hline \multirow[b]{2}{*}{ Sample ${ }^{b}$} & \multirow[b]{2}{*}{ Temperature $\left({ }^{\circ} \mathrm{C}\right)$} & \multirow[b]{2}{*}{ Time (days) } & \multicolumn{4}{|c|}{$\mathrm{Ct}$ value } & \multicolumn{3}{|c|}{ 'Ca. L. asiaticus' titer } \\
\hline & & & Initial & 30 DAT & 60 DAT & 270 DAT & Initial & 30 DAT & 270 DAT \\
\hline TOA 1 & 40 & 2 & 23.08 & 21.88 & ND & ND & $1.33 \mathrm{E}+09$ & $2.95 \mathrm{E}+09$ & ND \\
\hline TOA 2 & 40 & 2 & 22.77 & 20.20 & ND & ND & $1.64 \mathrm{E}+09$ & $8.94 \mathrm{E}+09$ & ND \\
\hline TOA 3 & 40 & 2 & 24.14 & 22.57 & ND & ND & $6.64 \mathrm{E}+08$ & $1.87 \mathrm{E}+09$ & ND \\
\hline TOA 4 & 40 & 4 & 19.34 & 21.68 & ND & ND & $1.58 \mathrm{E}+10$ & $3.37 \mathrm{E}+09$ & ND \\
\hline TOA 5 & 40 & 4 & 20.42 & 23.11 & ND & ND & $7.73 \mathrm{E}+09$ & $1.31 \mathrm{E}+09$ & ND \\
\hline TOA 6 & 40 & 4 & 24.26 & 21.90 & ND & ND & $6.14 \mathrm{E}+08$ & $2.91 \mathrm{E}+09$ & ND \\
\hline TOA 7 & 40 & 6 & 21.72 & 22.17 & ND & ND & $3.28 \mathrm{E}+09$ & $2.43 \mathrm{E}+09$ & ND \\
\hline TOA 8 & 40 & 6 & 24.43 & 23.06 & ND & ND & $5.49 \mathrm{E}+08$ & $1.35 \mathrm{E}+09$ & ND \\
\hline TOA 9 & 40 & 6 & 22.43 & 20.20 & ND & ND & $2.05 \mathrm{E}+09$ & $8.94 \mathrm{E}+09$ & ND \\
\hline TOA 10 & $42(19 h) 30(5 h)$ & 2 & 19.67 & 21.09 & ND & ND & $1.27 \mathrm{E}+10$ & $4.97 \mathrm{E}+09$ & ND \\
\hline TOA 11 & $42(19 \mathrm{~h}) 30(5 \mathrm{~h})$ & 2 & 21.87 & 23.37 & ND & ND & $2.97 \mathrm{E}+09$ & $1.10 \mathrm{E}+09$ & ND \\
\hline TOA 12 & $42(19 h) 30(5 h)$ & 2 & 23.89 & 22.57 & ND & ND & $7.83 \mathrm{E}+08$ & $1.87 \mathrm{E}+09$ & ND \\
\hline TOA 13 & $42(19$ h) $30(5 \mathrm{~h})$ & 4 & 18.42 & 20.56 & ND & ND & $2.89 \mathrm{E}+10$ & $7.05 \mathrm{E}+09$ & ND \\
\hline TOA 14 & $42(19$ h) $30(5 \mathrm{~h})$ & 4 & 26.72 & 25.34 & ND & ND & $1.21 \mathrm{E}+08$ & $3.01 \mathrm{E}+08$ & ND \\
\hline TOA 15 & $42(19$ h) $30(5 \mathrm{~h})$ & 4 & 20.91 & 23.53 & ND & ND & $5.60 \mathrm{E}+09$ & $9.93 \mathrm{E}+08$ & ND \\
\hline TOA 16 & $42(19$ h) $30(5 \mathrm{~h})$ & 6 & 21.61 & 21.90 & ND & ND & $3.53 \mathrm{E}+09$ & $2.91 \mathrm{E}+09$ & ND \\
\hline TOA 17 & $42(19$ h) $30(5 \mathrm{~h})$ & 6 & 21.69 & 23.25 & ND & ND & $3.35 \mathrm{E}+09$ & $1.20 \mathrm{E}+09$ & ND \\
\hline TOA 18 & $42(19 h) 30(5 \mathrm{~h})$ & 6 & 20.71 & 22.62 & ND & ND & $6.38 \mathrm{E}+09$ & $1.81 \mathrm{E}+09$ & ND \\
\hline TOA 19 & $45(16 \mathrm{~h}) 30(8 \mathrm{~h})$ & 2 & 21.01 & N/A & ND & ND & $5.24 \mathrm{E}+09$ & N/A & ND \\
\hline TOA 20 & $45(16 \mathrm{~h}) 30(8 \mathrm{~h})$ & 2 & 20.84 & N/A & ND & ND & $5.86 \mathrm{E}+09$ & N/A & ND \\
\hline TOA 21 & $45(16 \mathrm{~h}) 30(8 \mathrm{~h})$ & 2 & 15.76 & N/A & ND & ND & $1.67 \mathrm{E}+11$ & N/A & ND \\
\hline TOA 22 & $45(16 \mathrm{~h}) 30(8 \mathrm{~h})$ & 4 & 22.47 & N/A & ND & ND & $2.00 \mathrm{E}+09$ & N/A & ND \\
\hline TOA 23 & $45(16 \mathrm{~h}) 30(8 \mathrm{~h})$ & 4 & 21.23 & N/A & ND & ND & $4.53 \mathrm{E}+09$ & N/A & ND \\
\hline TOA 24 & $45(16 \mathrm{~h}) 30(8 \mathrm{~h})$ & 4 & 21.78 & N/A & ND & ND & $3.15 \mathrm{E}+09$ & N/A & ND \\
\hline TOA 25 & $45(16 \mathrm{~h}) 30(8 \mathrm{~h})$ & 6 & 20.78 & N/A & ND & ND & $6.10 \mathrm{E}+09$ & N/A & ND \\
\hline TOA 26 & $45(16 \mathrm{~h}) 30(8 \mathrm{~h})$ & 6 & 19.04 & N/A & ND & ND & $1.92 \mathrm{E}+10$ & N/A & ND \\
\hline TOA 27 & $45(16 \mathrm{~h}) 30(8 \mathrm{~h})$ & 6 & 19.80 & N/A & ND & ND & $1.16 \mathrm{E}+10$ & N/A & ND \\
\hline TOA $1 \mathrm{C}$ & No-treatment control & & 21.57 & N/A & 20.91 & 28.78 & $3.62 \mathrm{E}+09$ & N/A & $3.10 \mathrm{E}+07$ \\
\hline TOA $2 \mathrm{C}$ & No-treatment control & & 20.20 & N/A & 21.36 & 22.22 & $8.94 \mathrm{E}+09$ & N/A & $2.36 \mathrm{E}+09$ \\
\hline TOA 3C & No-treatment control & & 19.01 & N/A & N/A & DNS & $1.96 \mathrm{E}+10$ & N/A & DNS \\
\hline
\end{tabular}

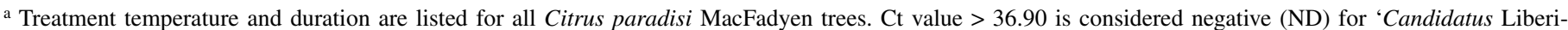
bacter asiaticus'. ND $=\mathrm{Ct}$ value was either $>36.9$ or not detected within 40 cycles of qPCR and sample was considered negative for 'Ca. L. asiaticus', N/A indicates that tree was not sampled, and DNS $=$ did not survive.

b Sample numbers ending in $\mathrm{C}$ refer to $\mathrm{C}$ refers to ' $\mathrm{Ca}$. L. asiaticus'-infected tree that received no treatment.

c ' $\mathrm{Ca}$. L. asiaticus' titer is per gram of tissue.

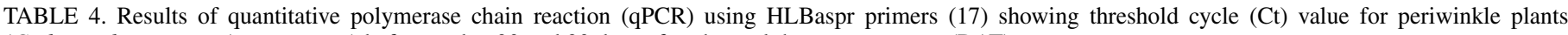
(Catharanthus roseus; Apocynaceae) before and at 30 and 90 days after thermal therapy treatment (DAT) ${ }^{\mathrm{a}}$

\begin{tabular}{|c|c|c|c|c|c|}
\hline \multirow[b]{2}{*}{ Sample } & \multirow[b]{2}{*}{ Temperature $\left({ }^{\circ} \mathrm{C}\right)$} & \multirow[b]{2}{*}{ Time (days) } & \multicolumn{3}{|c|}{$\mathrm{Ct}$ value } \\
\hline & & & Initial & 30 DAT & 90 DAT \\
\hline PW 501 & 40 & 10 & 24.5 & 30.82 & ND \\
\hline PW 502 & 40 & 10 & 24.85 & 24.85 & 21.06 \\
\hline PW 503 & 40 & 10 & 31.16 & ND & 35.03 \\
\hline PW 504 control 1 & 40 & 10 & ND & ND & ND \\
\hline PW 505 control 2 & 40 & 10 & ND & ND & ND \\
\hline PW 506 control 3 & 40 & 10 & ND & ND & ND \\
\hline PW B039 & 40 (7 days) 42 (7 days) & 14 & 22.98 & ND & ND \\
\hline PW B058 & 40 (7 days) 42 (7 days) & 14 & 22.44 & ND & ND \\
\hline PW B011 & 40 (7 days) 42 (7 days) & 14 & 22.37 & ND & ND \\
\hline PW 181 control 1 & 40 (7 days) 42 (7 days) & 14 & ND & ND & ND \\
\hline PW 065 control 2 & 40 (7 days) 42 (7 days) & 14 & ND & DNS & DNS \\
\hline PW 063 control 3 & 40 (7 days) 42 ( 7 days) & 14 & ND & ND & ND \\
\hline
\end{tabular}

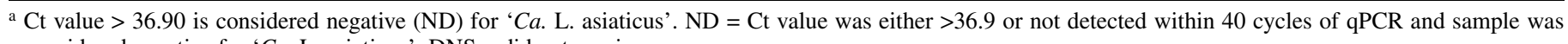
considered negative for ' $\mathrm{Ca}$. L. asiaticus'; DNS = did not survive. 
threshold, for a prolonged duration $(26,29)$. The heat-tolerance threshold differs among species and at different stages during plant development. The reaction to heat stress was noticeably different between citrus and periwinkle. In this study, when exposed to sustained high temperatures $\left(42^{\circ} \mathrm{C}\right)$, only leaf wilting was observed on periwinkle whereas, on citrus (all varieties tested), older leaves and any new flush displayed damage. Despite wilt and leaf damage at temperatures $\leq 42^{\circ} \mathrm{C}$, both groups of plants recovered well and continued to grow without exhibiting HLB disease symptoms.

During times of heat stress, several physiological changes occur in the plant that might help explain the results of this study. For the plants treated in this study, we would expect to see changes in respiration and membrane stability, combined with increasing amounts of hormones, secondary metabolites, reactive oxygen species, and stress-related proteins $(26,29)$. These events may factor into the response in extraordinary new flush and new root growth and vigor that we have documented here. Stress hormones such as abscisic acid, salicylic acid, and ethylene act as signal molecules to regulate numerous pathways and may contribute to the positive growth effects observed after heat treatment.

Alternatively or additionally, the reduction of ' $\mathrm{Ca}$. L. asiaticus' titer may be a direct result of heat stress on ' $\mathrm{Ca}$. L. asiaticus' bacteria. Two prophages, $\mathrm{SC} 1$ and $\mathrm{SC} 2$, are present in the genome of ' $\mathrm{Ca}$. L. asiaticus', and they can be induced to enter a lytic cycle (31). Phage lytic cycle induction can be triggered by environmental factors such as peroxides or antibiotics, which cause DNA damage to the bacterial cell, activating the oxidative stress (SOS) response $(6,24,30)$. In the well-studied $\lambda$ phage, the SOS response inactivates the phage CI protein, triggering the lytic cycle $(24,25)$. Heat stress has been shown to activate lytic induction in E. coli containing $\lambda$-lysogenic phage, phage containing strains of $X$. fastidiosa, and cyanobacteria harboring cyanophage $(3,5,25,27)$. High-temperature thermotherapy may have induced the SC1 and SC2 prophage to enter the lytic cycle in the entire ' $C a$. L. asiaticus' population within the potted citrus plants, killing the bacterium. Although phage DNA was detected after treatment, there was a decrease in measurable qPCR concentration when compared with before treatment levels (data not shown) (22). We are currently studying the mechanism of lytic induction of the phage in ' $\mathrm{Ca}$. L. asiaticus' to determine whether the phage has a direct role in the ' $\mathrm{Ca}$. L. asiaticus' reduction.

We have demonstrated that thermotherapy can eliminate ' $\mathrm{Ca}$. L. asiaticus' infection in potted citrus plants and that these plants remained disease free for over 2 years when not exposed to subsequent infection. Therefore, thermotherapy $\left(40\right.$ to $42^{\circ} \mathrm{C}$ for 7 to 10 days) could be useful in citriculture for reliable clean-up of ' $C a$. L. asiaticus'-infected germplasm and breeding materials, as well as the development of disease-free nurseries. Additional experiments are in place to determine whether thermotherapy is an effective treatment for HLB-positive dooryard citrus and trees in commercial groves. The most challenging factor in the field treatment is increasing and maintaining a relatively high temperature in the soil where citrus trees grow. Because HLB is a systemic disease, effective elimination of ' $\mathrm{Ca}$. L. asiaticus' bacteria from the entire citrus tree, including roots, is essential for curing the disease. To overcome this barrier, we are testing the effects of heat treatment combined with a chemical treatment on HLBaffected plants, which may lead to a practical solution for the control of citrus HLB in the field.

\section{ACKNOWLEDGMENTS}

This work was supported by grants from the Specialty Crop Block Grant, FDACS and the Citrus Research and Development Foundation, Inc. to Y.-P. Duan and D. W. Gabriel. We thank C. Latza, P. Rayside, G. Brock, and J. Smith for excellent technical assistance; and R. Shatter and A. Voss for providing infected citrus.

\section{LITERATURE CITED}

1. Aubert, B., Garnier, M., Cassin, J. C., and Bertin, Y. 1988. Citrus greening disease survey in East and West African countries south of the Sahara. Pages 231-237 in: 10th Conf. Int. Organ. Citrus Virol. L. W. Timmer, S. M. Garnsey, and L. Navarro, eds. IOCV, Riverside, CA.

2. Bové, J. M., Calavan, E. C., Capoor, S. P., Cortez, R. E., and Schwarz, R. E. 1974. Influence of temperature on symptoms of California stubborn, South African greening, Indian citrus decline and Philippines leaf mottling diseases. Pages 12-15 in: 6th Conf. Int. Organ. Citrus Virol. L. G. Weathers and M. Cohen, eds. IOCV, Riverside, CA

3. Chu, T.-C., Murray, S. R., Hsu, S.-F., Vega, Q, and Lee, L. H. 2011. Temperature-induced activation of freshwater Cyanophage AS-1 prophage. Acta Histochem. 113:294-299.

4. Damann, K. E., Jr., and Benda, G. T. A. 1983. Evaluation of commercial heat-treatment methods for control of ratoon stunting disease of sugarcane. Plant Dis. 67:966-967.

5. de Mello Varani, A, Souza, R. C., Nakaya, H. I., de Lima, W. C., Paula de Almeida, L. G., Kitajima, E. W., Chen, J., Civerolo, E., Vasconcelos, A. T. R., and Van Sluys, M.-A. 2008. Origins of the Xylella fastidiosa prophage-like regions and their impact in genome differentiation. PLoS ONE 3:e4059.

6. Echols, H. 1986. Bacteriophage $\lambda$ development: Temporal switches and the choice of lysis or lysogeny. Trends Genet 2:26-30.

7. Garnier, M., and Bové, J. M. 1983. Transmission of the organism associated with citrus greening disease from sweet orange to periwinkle by dodder. Phytopathology 73:1358-1363.

8. Gasparoto, M. C. G., Coletta-Filho, H. D., Bassanezi, R. B., Lopes, S. A., Lourenço, S. A., and Amorim, L. 2012. Influence of temperature on infection and establishment of 'Candidatus Liberibacter asiaticus' in citrus plants. Plant Pathol. 61:658-664.

9. Gottwald, T. R. 2007. Citrus canker and citrus Huanglongbing, two exotic bacterial diseases threatening the citrus industries of the western hemisphere. Outlooks Pest Manage. 18:274-279.

10. Grant, T. J. 1957. Heat treatments for obtaining sources of virus-free citrus budwood. Fla. State Hortic. Soc. 70:51-53.

11. Grant, T. J., Jones, J. W., and Norman, G. C. 1959. Present status of heat treatment of citrus viruses. Fla. State Hortic. Soc. 72:45-48.

12. Hodges, Alan W, and Spreen, Thomas H. 2012. Economic Impacts of Citrus Greening (HLB) in Florida, 2006/07-2010/11. Food and Resource Economics Department, Florida Cooperative Extension Service, Institute of Food and Agricultural Sciences, University of Florida, Gainesville.

13. Hoy, J. W., and Flynn, J. L. 2001. Control of ratoon stunting disease of sugarcane in Louisiana with seedcane produced through micropropagation and resistant cultivars. Proc. Int. Soc. Sugar Cane Technol. 24:417421.

14. Jagoueix, S, Bové, J. M, and Garnier, M. 1994. The phloem-limited bacterium of greening disease of citrus is a member of the alpha subdivision of the Proteobacteria. Int. J. Syst. Bacteriol. 44:379-386.

15. Jagoueix, S, Bové, J. M, and Garnier, M. 1996. PCR detection of the two 'Candidatus' liberobacter species associated with greening disease of citrus. Mol. Cell Probe 10:43-50.

16. Kunkel, L. O. 1936. Heat treatment for the control of yellows and other virus diseases of peach. Phytopathology 26:809-830.

17. Li, W., Hartung, J. S., and Levy, L. 2006. Quantitative real-time PCR for detection and identification of Candidatus Liberibacter species associated with citrus huanglongbing. J. Microbiol. Methods 66:104-115.

18. Li, W., Li, D., Twieg, E., Hartung, J. S., and Levy, L. 2008. Optimized quantification of unculturable Candidatus Liberibacter spp. in host plants using real-time PCR. Plant Dis. 92:854-861.

19. Lo, X. 1983. Studies on the sterilization effect of the intermittent hot water treatment on citrus budwood and nursling infected with citrus yellow shoot. J. S. China Agric. Univ. 1:97-102.

20. Lo, X., Lo, D., and Tang, W. 1981. Studies on the thermotherapy of citrus yellow shoot disease. Acta Phytophylac. Sin. 8:47-51.

21. Lopes, S. A., Frare, G. F., Bertolini, E., Cambra, M., Fernandes, N. G., Ayres, A. J., Marin, D. R., and Bové, J. M. 2009. Liberibacters associated with citrus huanglongbing in Brazil 'Candidatus Liberibacter asiaticus' is heat tolerant, 'Ca. L americanus' is heat sensitive. Plant Dis. 93:257-262.

22. Morgan, K., Zhou, L., Li, W., Shatters, R. G., Keremane, M., and Duan, Y. P. 2012. Improved real-time PCR detection of 'Candidatus Liberibacter asiaticus' from citrus and psyllid hosts by targeting the intragenic tandem repeats of its prophage genes. Mol. Cell Probe 26:90-98.

23. Nyland, G., and Goheen, A. C. 1969. Heat therapy of virus diseases of perennial plants. Annu. Rev. Phytopathol. 7:331-354.

24. Oppenheim, A. B., Kobiler, O., Stavans, J., Court, D. L., and Adhya, S. 2005. Switches in bacteriophage lamda development. Annu. Rev. Genet. 39:409-429.

25. Rokney, A., Kobiler, O., Amir, A., Court, D. L., Stavans, J., Adhya, S., and Oppenheim, A. B. 2008. Host responses influence on the induction of 
lambda prophage. Mol. Microbiol. 68:29-36.

26. Saidi, Y., Finka, A., and Goloubinoff, P. 2011. Heat perception and signaling in plants: a tortuous path to thermotolerance. New Phytol. 190:556-565

27. Schuster, H., Beyersmann, M., Mikolajczyk, M., and Schlight, M. 1973. Prophage induction by high temperature in thermosensitive dna mutants lysogenic for bacteriophage lambda. J. Virol. 11:879-885.

28. Viswanathan, R. 2001. Different aerated steam therapy (AST) regimes on the development of grassy shoot disease symptoms in sugarcane. Sugar Technol. 3:83-91.
29. Wahid, A, Gelani, S, Ashraf, M, and Foolad, M. R. 2007. Heat tolerance in plants: An overview. Environ. Exp. Bot. 61:199-223.

30. Węgrzyn, G., Węgrzyn, A., and Kivie, M. 2005. Genetic switches during bacteriophage $\lambda$ development. Prog. Nucleic Acid Res. Mol. Biol. 79:148.

31. Zhang, S., Flores-Cruz, Z., Zhou, L., Kang, B. H., Fleites, L. A., Gooch, M. D., Wulff, N. A., Davis, M. J., Duan, Y. P., and Gabriel, D. W. 2011. ' $\mathrm{Ca}$. Liberibacter asiaticus' carries an excision plasmid prophage and a chromosomally integrated prophage that becomes lytic in plant infections. Mol. Plant-Microbe Interact. 24:458-468. 